\title{
PARTISIPASI MASYARAKAT TERHADAP UPAYA PENGENTASAN KEMISKINAN BERBASIS PEMBERDAYAAN PEREMPUAN MELALUI PROGRAM P3EL KABUPATEN SIDOARJO
}

\author{
Effy Wardati Maryam, Ririn Dewanti \\ Fakultas Psikologi Universitas Muhammadiyah Sidoarjo
}

\begin{abstract}
Women are the group most severely affected by poverty, especially in case of food insecurity. As a result of these conditions, pregnant mothers could malnutrition that can potentially give birth in poor mental or health condition. Poverty reduction is not merely the issue of capital and technical skills, but also how to evoke the feeling of being able to overcome problems of their lives in a dignified manner. Empowerment of poor women do in order to find the effort that poor women can actively participate in any activities for poverty alleviation. This study aims to assess community participation, particularly of women to poverty alleviation efforts based on empowerment. This research was descriptive-exploratory using primary data sources from interviews and secondary data sources of written documents on the implementation of the Programme P3EL in Sidoarjo. Subjects were members P3EL program in 2012 and the BPMPKB (particularly the PUE) as the implementing program. The results showed that the model of participation of members to poverty alleviation efforts based on the empowerment of women through P3EL program were in the form of energy, thoughts, and cooperation. While the participation factors underlying were egoism motivation and collectivism.
\end{abstract}

Keywords: participation, poverty alleviation efforts, women empowerment

\begin{abstract}
ABSTRAK
Perempuan merupakan kelompok yang paling menderita akibat dari kemiskinan, terutama jika terjadi kerawanan pangan. Akibat dari kondisi ini, Ibu-ibu hamil bisa kekurangan gizi yang bisa berpotensi melahirkan bayi dalam kondisi buruk mental maupun kesehatan. Pengentasan kemiskinan bukan semata-mata persoalan permodalan dan ketrampilan teknis, melainkan juga bagaimana membangkitkan perasaan untuk mampu mengatasi permasalah hidup mereka dengan cara yang bermartabat. Pemberdayaan pada perempuan miskin dilakukan dalam rangka untuk menemukan upaya agar perempuan miskin bisa secara aktif berpartisipasi dalam setiap kegiatan untuk pengentasan kemiskinan. Penelitian ini bertujuan untuk mengkaji tentang partisipasi masyarakat, khususnya perempuan terhadap upaya pengentasan kemiskinan yang berbasis pada pemberdayaan. Jenis penelitian ini adalah deskriptif-eksploratif dengan menggunakan sumber data primer dari wawancara dan sumber data sekunder dari dokumen tertulis tentang pelaksanaan Program P3EL di Kabupaten Sidoarjo. Subjek penelitian adalah anggota Program P3EL Tahun 2012 dan pihak BPMPKB (khususnya bidang PUE) sebagai pelaksana Program. Hasil penelitian menunjukkan bahwa model partisipasi anggota terhadap upaya pengentasan kemiskinan berbasis pemberdayaan perempuan melalui Program P3EL adalah berupa tenaga, pemikiran, dan kerjasama. Sedangkan faktor-faktor yang mendasari partisipasi adalah motif egoisme dan kolektivisme.
\end{abstract}

Kata kunci: partisipasi, pengentasan kemiskinan, pemberdayaan perempuan

\section{PENDAHULUAN}

Kemiskinan yang terjadi di tengah masyarakat disebabkan oleh berbagai faktor yang rumit dan saling terkait erat satu dengan yang lainnya. Kondisi tersebut sering dikatakan sebagai suatu pola "lingkaran setan" yang sangat sulit untuk dipecahkan. Pola tersebut berlangsung secara terus menerus dan bahkan cenderung menimbulkan dampak yang semakin buruk. Menurut Maskun (1997), kondisi kemiskinan dapat disebabkan oleh 
rendahnya tingkat pendidikan, rendahnya derajat kesehatan, terbatasnya lapangan kerja dan kondisi keterisolasian, serta motivasi dan kesadaran dari orang miskin untuk lepas dari kungkungan kemiskinan yang menghimpit.

Kemiskinan membatasi akses manusia terhadap pendidikan, kesehatan, perlindungan hukum, serta pelayanan publik lainnya. Selain itu, kemiskinan hanya akan membawa keterpurukan dan isolasi sosial. Kondisi kemiskinan dan keterbatasan tersebut akan mempengaruhi kualitas hidup secara umum atau kesejahteraan hidup (well-being) masyarakat. Kesejahteraan hidup sendiri oleh Seligman (2002 dalam Diener \& Seligman, 2004) didefinisikan sebagai "penilaian positif seseorang atas kehidupannya, termasuk emosi, penghayatan, kepuasan, dan makna yang positif".

Orang-orang miskin hidup dengan berbagai keterbatasan dan kekurangan, dimana berbagai kekurangan yang mereka miliki dapat menyebabkan munculnya berbagai ketidakberdayaan, terutama yang berhubungan dengan pemenuhan kebutuhan finansial. Selain ketidakberdayaan secara finansial, orangorang miskin juga memiliki ketidakberdayaan secara psikologis. Penelitian yang dilakukan oleh Parker dan Kleiner (1993, dalam Arbiyah, 2008) menunjukkan bahwa orang-orang yang hidup dalam kemiskinan lebih cenderung merasa pesimis terhadap kemungkinan mereka untuk dapat berhasil. Rasa pesimis menunjukkan adanya pemaknaan yang negatif terhadap kehidupan. Padahal, ketidakberdayaan sendiri tidak selalu harus menyebabkan munculnya pemaknaan hidup yang negatif.

Perempuan merupakan sosok penting dalam menentukan kualitas hidup keluarga dan sebagai bagian dari komunitas masyarakat. Perempuan memiliki peran dan fungsi yang strategis. Namun, peranan itu masih sulit diwujudkan karena kemiskinan. Kelompok perempuan merupakan kelompok yang paling menderita sebagai akibat dari kemiskinan, terutama jika terjadi kerawanan pangan. Ibu-ibu hamil bisa kekurangan gizi sehingga melahirkan balita yang buruk kondisi kesehatan dan mentalnya.

Hasil penelitian yang dilakukan oleh Mulia, Schmidt, Bond, Jacobs, dan Korcha (2008) menyatakan bahwa kemiskinan yang melanda perempuan menyebabkan stress. Perempuan miskin sering merasa kurang bahagia dan bahkan mengalami gangguan mental yang serius, seperti depresi, skizofrenia, dan gangguan kepribadian, sebagai akibat tekanan ekonomi atau menanggung beban hidup yang berat. Beberapa kasus seperti seorang ibu yang membunuh anak kandungnya sendiri, bisa dijadikan sebagai gambaran stres yang dialami oleh perempuan miskin sebagai akibat tekanan ekonomi.

Berdasarkan hasil penelitian ahli lain, dapat digeneralisasaikan bahwa kemiskinan lebih banyak diderita oleh perempuan (Todarodalam , Kumurur, 2009). Menurut Todaro (dalam Kumurur, 2009), di dunia ketiga terungkap fakta bahwa kaum perempuan beserta anakanaknya paling menderita kekurangan gizi, paling sedikit menerima pelayanan kesehatan, air bersih, sanitasi dan berbagai bentuk pelayanan sosial lainnya. Todaro (dalam Kumurur, 2009) mengemukakan bahwa banyak perempuan yang menjadi kepala-kepala rumah tangga, memiliki kapasitas yang rendah dalam menghasilkan pendapatan sendiri, dan terbatas kontrol terhadap pendapatan suami. Sementara itu lanjut Todaro (dalam Kumurur, 2009), bahwa perempuan memiliki keterbatasan akses dalam memperoleh pendidikan, pekerjaan yang layak di sektor formal, tunjangan-tunjangan sosial dan programprogram penciptaan lapangan pekerjaan yang diciptakan pemerintah.

Menurut Ortigas (dalam Markum, 2009), bahwa pengentasan kemiskinan bukan semata-mata persoalan permodalan dan ketrampilan teknis, melainkan 
bagaimana membangkitkan perasaan mampu mengatasi hidup di kalangan orang miskin dengan cara yang bermartabat dan menjaga harga diri. Orang miskin harus diyakinkan bahwa mereka memiliki kemampuan atau ketrampilan tertentu (self-efficacy) yang selanjutnya akan menumbuhkan harga diri mereka (selfesteem) sehingga mampu melakukan sesuatu, diharapkan orang miskin menjadi tahan banting dan mampu bangkit kembali (self-reliance) ketika mereka menghadapi situasi yang sulit dan berat. Upaya-upaya untuk menumbuhkan self efficacy, self reliance dan kemandirian melalui program pemberdayaan (empowerment) harus dijadikan prioritas dalam upaya pengentasan kemiskinan (Markum, 2009). Pemberdayaan pada perempuan miskin dilakukan dalam rangka untuk menemukan upaya agar perempuan miskin bisa secara aktif berpartisipasi dalam setiap kegiatan untuk pengentasan kemiskinan.

Saat ini mulai muncul upaya pemberdayaan perempuan untuk pengentasan kemiskinan. Hal ini didukung oleh rekomendasi untuk pencapaian pembangunan sesuai dengan Millenium Development Goals (MDGs) atau tujuan pembangunan milenium, yakni meningkatkan peran perempuan agar menjadi perhatian khusus dalam proses pembangunan. Program pembangunan akan berhasil dengan meningkatkan posisi perempuan dalam masyarakat, sesuai dengan salah satu tujuan pembangunan MDGs yang salah satu indikator pencapaian pada tahun 2015 adalah mendorong pemberdayaan perempuan dalam upaya mengurangi angka kemiskinan (Brodjonegoro, 2007).

Lebih lanjut Orford (2008) menjelaskan bahwa pemberdayaan perempuan sebaiknya lebih terfokus pada ibu, karena ibu merupakan pemberi perawatan utama dalam keluarga dan relatif tidak berdaya dibandingkan lakilaki, serta memiliki kecenderungan untuk memberikan prioritas yang tinggi pada kesejahteraan anak-anak dan keluarga daripada untuk kebutuhan sendiri. Beberapa model pengembangan masyarakat yang inovatif dan dianggap baik menemukan bahwa pemberdayaan masyarakat, khususnya pemberdayaan pada perempuan, adalah kunci suksesnya program perubahan sosial untuk merubah kualitas hidup dan kesehatan masyarakat ke arah yang lebih baik. Bahkan menurut Kar, et all (1999 dalam Orford, 2008), bahwa perempuan dan ibu (woman and mother ( WAM) dalam situasi yang paling disenfranchised (kehilangan haknya) dan terpuruk, masih dapat melakukan tindakan yang berhasil memimpin gerakan sosial yang memberdayakan diri, dan secara signifikan mampu meningkatkan kualitas hidup keluarga mereka dan masyarakat. Pemberdayaan pada perempuan miskin dilakukan dalam rangka untuk menemukan upaya agar perempuan miskin bisa secara aktif berpartisipasi dalam setiap kegiatan untuk pengentasan kemiskinan.

Salah satu program pengentasan kemiskinan melalui pemberdayaan perempuan yang dikelola oleh Pemerintah Kabupaten Sidoarjo adalah Program Pemberdayaan Perempuan Pengembang Ekonomi Lokal (P3EL) yang diterapkan mulai tahun 2010. Program ini merupakan program pemberdayaan yang diperuntukkan bagi perempuan dalam rangka meningkatkan pendapatan untuk kesejahteraan keluarga. Program P3EL merupakan upaya dari Gerakan Ekonomi Keluarga Sejahtera dalam rangka meningkatkan tahapan keluarga sejahtera, khususnya di bidang ekonomi yang dikaitkan dengan upaya penanggulangan kemiskinan. Prioritas utama dari Gerakan Ekonomi Keluarga ini adalah memberdayakan keluarga yang paling lemah, yaitu Keluarga Pra Sejahtera dan Keluarga Sejahtera I agar mereka dapat terlepas dari keterbelakangan sosial ekonomi (BPMPKB Kabupaten Sidoarjo, 2010).

Implementasi dari Program P3EL adalah dengan memberikan bantuan modal kepada kelompok perempuan yang 
memiliki usaha dengan modal minim (seperti "bakul" atau pedagang makanan). Berdasarkan hasil penelitian Ridaningrum (2008) tentang Program P3EL ditemukan bahwa pemahaman dasar atas Program P3EL kurang mendalam ditanamkan pada kelompok sasaran, akibatnya mereka merasa bahwa Program P3EL bukan program pemberdayaan melainkan program bagi-bagi uang kepada perempuan.

Seharusnya pengentasan kemiskinan merupakan sebuah upaya yang dilakukan untuk mengurangi atau menurunkan angka kemiskinan (Markum, 2009). Upaya pengentasan kemiskinan di Indonesia sudah berlangsung sejak lama dan telah melibatkan pihak pemerintah, swasta, LSM, dan partai politik. Upaya pengentasan kemiskinan bisa dilakukan melalui tiga sasaran (Markum, 2009) sebagai berikut : (a). Intervensi individual, merupakan intervensi yang dilakukan dengan merubah mind-set orang miskin, yaitu dengan cara meyakinkan orang miskin bahwa mereka memiliki kemampuan atau ketrampilan tertentu (self-efficacy) yang selanjutnya akan tumbuh harga diri mereka (selfesteem). (b). Intervensi kultural, yang dilakukan pada tingkatan ini adalah merubah kultur kemiskinan (seperti tidak adanya perencanaan hidup dan tidak dapat menunda kesenangan), sehingga model penyaluran bantuan langsung tunai (BLT) tidak dapat dijadikan program jangka panjang karena justru akan berakibat memantapkan kultur kemiskinan. Oleh karena itu, upaya-upaya untuk menumbuhkan self-efficacy, self-reliance dan kemandirian melalui empowerment harus dijadikan prioritas dalam intervensi kemiskinan. (c). Intervensi struktural, yaitu dengan memprioritaskan dibukanya akses orang miskin terhadap pendidikan, kesehatan, perumahan, permodalan, dan program welfare lainnya.

Pemberdayaan

(empowerment) adalah suatu proses yang sedang dan terus berlangsung secara sengaja, berpusat pada masyarakat lokal yang berpikiran kritis, memiliki prinsip saling menghormati, kepedulian terhadap sesama dan partisipasi kelompok, dimana melalui proses ini individu-individu yang tidak memiliki akses akan keadilan alokasi sumber daya, memiliki akses dan kendali akan sumber daya tersebut (Rappaport's dalam Rudkin, 2003).

Secara prinsip dikemukakan bahwa konsep pemberdayaan perempuan dalam bidang ekonomi mencakup tiga hal (Sukesi, 2002), yaitu : (a). Capacity building, merupakan upaya membangun kemampuan perempuan. (b). Cultur change, merupakan perubahan-perubahan budaya yang memihak perempuan. (c). Structural adjusment, merupakan penyesuaian terhadap struktural yang juga memihak kepada kaum perempuan. Tiga hal tersebut diharapkan dapat diterjemahkan dalam setiap program pemberdayaan perempuan yang dibuat oleh pemerintah untuk menanggulangi kemiskinan.

Pemberdayaan merupakan sebuah upaya untuk mewujudkan perubahan sosial, salah satunya yaitu untuk mengatasi kemiskinan. Menurut Rappaport (dalam Rudkin, 2003), perubahan sosial tersebut tidak semata-mata dilakukan atau digerakkan oleh lembaga yang berwenang (lembaga profesional), melainkan dilakukan secara bersama-sama dengan seluruh anggota dalam sebuah komunitas. Keberhasilan sebuah program pengentasan kemiskinan yang berlandaskan pada pemberdayaan ditentukan oleh partisipasi masyarakat. Penanggulangan kemiskinan bisa cepat tercapai jika berdasarkan pada pengembangan kemandirian masyarakat melalui peningkatan partisipasi masyarakat. Parisipasi masyarakat (termasuk perempuan) secara aktif, akan mampu memenuhi kebutuhan mereka sesuai potensinya (Ife \& Tesoriero, 2008). Berdasarkan latar belakang di atas, maka penelitian ini dilakukan untuk mengkaji secara mendalam tentang partisipasi masyarakat khususnya perempuan terhadap upaya pengentasan kemiskinan 
berbasis pemberdayaan perempuan pada Program P3EL di Sidoarjo.

\section{METODE PENELITIAN}

Penelitian ini termasuk jenis penelitian deskriptif-eksploratif, yaitu suatu prosedur penelitian yang menghasilkan data deskriptif berupa katakata tertulis atau lisan dari orang-orang dan perilaku yang dapat diamati (Moleong, 2009).

Penelitian ini dilakukan di Kabupaten Sidoarjo, tepatnya di lima kecamatan yaitu Kecamatan Candi, Kecamatan Prambon, Kecamatan Tulangan, Kecamatan Gedangan, dan Kecamatan Sidoarjo, dengan pertimbangan bahwa berdasarkan keterangan dari pihak Badan Pemberdayaan Masyarakat, Perempuan, dan Keluarga Berencana (BPMPKB) Kabupaten Sidoarjo, di lima kecamatan tersebut banyak masyarakat (khususnya perempuan) yang menjadi anggota Program P3EL.

Subjek yang digunakan dalam penelitian ini adalah perempuan sejumlah 12 orang yang menjadi anggota Program Pemberdayaan Perempuan Pengembang Ekonomi Lokal (P3EL) Tahun 2012 (penerima bantuan pinjaman modal Program P3EL di Kabupaten Sidoarjo). Selain itu, penelitian ini juga menggunakan significant other, yaitu pelaksana Program P3EL di Kabupaten Sidoarjo (pihak BPMPKB) sejumlah 3 orang.

Teknik pengumpulan data pada penelitian ini menggunakan wawancara sebagai data primer, dilakukan kepada masyarakat yang menjadi anggota Program P3EL dan pelaksana Program P3EL. Selain wawancara, juga menggunakan studi dokumen, yaitu pedoman umum tentang pelaksanaan kegiatan Program P3EL di Sidoarjo Tahun 2012.

\section{HASIL DAN PEMBAHASAN}

\section{A. Penerapan Program P3EL}

Program P3EL diperuntukkan bagi perempuan di masing-masing desa atau kelurahan, baik yang sudah memiliki usaha dengan modal kecil, maupun yang akan merintis usaha. Program P3EL sebagai program pengentasan kemiskinan di Kabupaten Sidoarjo dilaksanakan melalui pemberian bantuan modal kepada kelompok perempuan yang memiliki usaha dengan modal minim (seperti "bakul" atau pedagang makanan). Setiap kelompok memperoleh pinjaman modal usaha sebesar Rp 10.000.000,- (sepuluh juta rupiah) dengan bunga sebesar $6 \%$ per tahun. Dana tersebut kebanyakan dikelola dalam bentuk simpan pinjam. Anggota hanya memperoleh pinjaman satu kali. Tanggung jawab pinjaman bantuan modal bersifat tanggung renteng terhadap anggota kelompok yang bersangkutan, artinya jika ada anggota dalam sebuah kelompok yang pembayaran angsurannya nunggak atau tidak membayar, maka akan ditanggung bersama oleh seluruh anggota kelompok.

Pinjaman modal yang diterapkan secara bergulir dimana anggota Program P3EL harus mengembalikan pinjaman modal tersebut dalam jangka waktu satu tahun dengan bunga sebesar enam persen tersebut dirasakan oleh sebagian anggota cukup menguntungkan, karena dengan sistem ini mampu mendorong anggota Program P3EL untuk menggunakan dana pinjaman tersebut untuk melakukan kegiatan ekonomi produktif, yaitu dengan membuka usaha seperti pracangan atau toko sehingga bisa menambah pendapatan keluarga.

Program P3EL memberikan pinjaman modal dengan bunga yang kecil, pengembalian bisa diangsur selama satu tahun. Hal ini menguntungkan bagi kelompok masyarakat miskin khususnya ibu-ibu karena keadaan perekonomian mereka yang pas-pasan sehingga tidak memungkinkan untuk pinjam modal dengan bunga yang tinggi. Tanggung jawab pengembalian pinjaman modal sifatnya "tanggung renteng", yakni jika ada anggota yang nunggak atau tidak 
membayar angsuran maka harus ditanggung bersama oleh anggota dalam satu kelompok.

Selain pinjaman modal bergulir, Program P3EL juga mengadakan kegiatan pelatihan ketrampilan dan penyuluhan tentang penggunaan modal dengan mendatangkan pembicara yang kompeten, yang dilaksanakan satu kali dalam satu tahun, seperti pelatihan kuliner, tata boga, dan menjahit. Jenis kegiatan pelatihan ditentukan oleh pelaksana Program P3EL di tingkat kabupaten. Kegiatan ini bertujuan untuk meningkatkan kemampuan dan ketrampilan perempuan sehingga bisa mengelola kegiatan usaha yang produktif. Sedangkan kegiatan penyuluhan pengembangan modal bertujuan untuk memberikan pengetahuan dan meningkatkan kemampuan perempuan dalam mengelola pinjaman modal yang diterima.

\section{B. Partisipasi Perempuan Terhadap Upaya Pengentasan Kemiskinan Berbasis Pemberdayaan Pada Program P3EL}

Partisipasi masyarakat dinilai oleh Putnam sebagai salah satu dari modal sosial (Putnam dalam Campbell dan Gillies, 2001). Partisipasi masyarakat dalam konteks psikologi didefinisikan sebagai keterlibatan dalam aktivitas terorganisir apapun yang dilakukan secara sukarela, sadar dan bertujuan untuk mencapai tujuan yang sama (Zimmerman \& Rappaport, 1988 dalam Duffy \&Wong, 2003). Partisipasi berarti mendorong proses belajar bersama, berkomunikasi yang seimbang dalam membahas persoalan bersama, menjadikan kesepakatan sebagai sumber utama dalam pengambilan keputusan dan memberi ruang bagi masyarakat untuk mengontrol keputusan publik agar dilaksanakan sesuai dengan tujuan yang ditetapkan. Partisipasi merupakan keterlibatan seseorang dalam suatu kegiatan di lingkungannya yang dilakukan secara sadar dan sukarela demi mencapai tujuan bersama (Amandasani, 2011).

Partisipasi masyarakat (termasuk di dalamnya perempuan) merupakan salah satu metode yang digunakan untuk melakukan pemberdayaan guna menciptakan perubahan sosial seperti masalah kemiskinan. Partisipasi tersebut melibatkan kognisi, emosi, dan motivasi terutama untuk mengubah kehidupan komunitas dengan memanfaatkan kemampuan kolektif mereka. Bekerjasama dengan orang lain untuk memperbaiki kualitas hidup (dalam penelitian ini berkaitan dengan pengentasan kemiskinan), memerlukan keahlian khusus seperti kemampuan untuk bekerjasama, prososial, dinamika kelompok, kepemimpinan, penyelesaian konflik antar kelompok maupun di dalam kelompok sendiri (Wibowo, dkk., 2011).

Partisipasi perempuan terhadap upaya pengentasan kemiskinan pada Program P3EL di Kabupaten Sidoarjo, dilakukan secara aktif dalam bentuk aksi bersama (group action) di dalam memecahkan masalah dan memenuhi kebutuhan-kebutuhannya berdasarkan potensi-potensi yang dimiliki mereka, seperti mengikuti kegiatan-kegiatan yang diadakan oleh Program P3EL dan turut memberikan masukan tentang jenis pelatihan ketrampilan yang sesuai dengan kebutuhan mereka. Pengkajian atau analisis terhadap kebutuhan dan harapan dapat memberikan tambahan informasi, serta sebagai kelengkapan data dalam menentukan keputusan selanjutnya tentang bentuk-bentuk kegiatan pelatihan ketrampilan. Kebutuhan dan harapan ini bukan muncul dari perkiraan pelaksana Program P3EL, akan tetapi benar-benar berasal dari masyarakat perempuan yang menerima bantuan modal, sehingga kegiatan pelatihan ketrampilan yang diadakan memang sesuai dengan apa yang dibutuhkan oleh mereka. Keterlibatan perempuan pada kegiatan-kegiatan yang diadakan oleh Program P3EL, diharapkan 
mampu memecahkan masalah yang mereka hadapi sesuai dengan potensinya.

Berdasarkan hasil penelitian, diperoleh gambaran tentang bentuk partisipasi perempuan dalam upaya pengentasan kemiskinan berbasis pemberdayaan pada Program P3EL di Kabupaten Sidoarjo, sebagai berikut :

1. Partisipasi berupa tenaga (physical participation).

Partisipasi ini diberikan dalam bentuk tenaga dengan melibatkan diri dalam suatu aktifitas dengan maksud tertentu (Keit Davis dalam Sakdiyah, 2006). Masyarakat perempuan yang menjadi anggota Program P3EL berpartisipasi dalam kegiatan pelatihan ketrampilan dan penyuluhan pengembangan modal yang diselenggarakan oleh pihak BPMPKB sebagai pelaksana Program P3EL di Sidoarjo. Kegiatan pelatihan bertujuan untuk meningkatkan kemampuan dan ketrampilan anggota sehingga mereka bisa mengelola kegiatan usaha ekonomi yang produktif, sedangkan kegiatan penyuluhan pengembangan modal bertujuan untuk memberikan pengetahuan dan meningkatkan kemampuan anggota dalam mengelola pinjaman modal yang diterima.

Kegiatan pelatihan tersebut tidak diikuti oleh semua anggota Program P3EL karena kegiatan pelatihan hanya dilakukan sekali dalam satu tahun dengan jumlah peserta yang dibatasi karena persoalan keterbatasan dana. Selain itu, jenis pelatihan juga dirasakan kurang sesuai dengan kebutuhan anggota. Adanya pembatasan jumlah peserta yang ikut dan ketidaksesuaian jenis pelatihan ketrampilan dengan jenis usaha yang dijalani anggota, menyebabkan tidak semua anggota mengikuti kegiatan pelatihan dan penyuluhan tersebut yang diselenggarakan oleh Program P3EL.

2. Partisipasi berupa kerjasama atau networking antar anggota kelompok
Partisipasi yang dilakukan bisa dalam bentuk menjalin kerjasama antar anggota dalam kelompok untuk bersama-sama mengatasi persoalan yang dihadapi (Fisher, dkk. 2002, Dudgeon, dkk. 2002, Putnam dalam Nelson dan Prilleltensky, 2005). Program P3EL sebagai program pemberdayaan perempuan untuk mengentaskan kemiskinan menerapkan pendekatan kelompok, yaitu melalui pembentukan kelompok usaha yang memungkinkan anggota untuk membentuk jaringan kerjasama dan memperoleh dukungan sosial dari anggota lain dalam kelompok sebagai upaya untuk mengatasi persoalan kemiskinan.

Melalui pembentukan kelompok ini, perempuan yang menjadi anggota Program P3EL bisa berbagi pengalaman dalam kegiatan produksi. Apabila dilakukan secara sendirisendiri, perempuan dengan keadaan perekonomian rendah sulit untuk dapat memecahkan masalah-masalah yang dihadapinya. Selain itu, lingkup bantuan menjadi terlalu luas jika penanganannya dilakukan secara individu. Pendekatan kelompok ini paling efektif dan penggunaan sumber daya juga lebih efisien. Pembentukan kelompok ini juga memudahkan pelaksana Program P3EL dalam mengendalikan pengembalian pinjaman modal, karena ketua kelompok menjadi penanggung jawab dalam pengembalian modal anggota. Sistem "gandeng renteng" yang diterapkan Program P3EL menguntungkan anggota kelompok, memotivasi serta menumbuhkan rasa kebersamaan dan tanggung jawab.

3. Partisipasi berupa sumbangan pemikiran (psychological participation)

Wujud partisipasi perempuan sebagai anggota Program P3EL yaitu keikutsertaan secara aktif dengan mengerahkan pikiran dalam suatu 
rangkaian kegiatan untuk mencapai tujuan tertentu. Anggota Program P3EL memberikan sumbangan pemikiran berupa usulan-usulan tentang jenis kegiatan pelatihan yang memang diperlukan bagi anggota. Usulan tersebut membantu pihak pelaksana Program P3EL dalam menentukan jenis kegiatan pelatihan yang bermanfaat bagi perempuan melalui bekal ketrampilan mengelola kegiatan usaha ekonomi yang produktif untuk mengurangi persoalan kemiskinan.

Sumbangan pemikiran dari perempuan yang menjadi anggota Program P3EL diharapkan dapat memberikan tambahan informasi dan sebagai kelengkapan data dalam menentukan keputusan selanjutnya tentang bentuk-bentuk kegiatan pelatihan ketrampilan. Kebutuhan dan harapan ini bukan muncul dari perkiraan pelaksana Program P3EL, akan tetapi benar-benar berasal dari anggota sebagai penerima bantuan modal sehingga kegiatan pelatihan ketrampilan yang diadakan memang sesuai dengan apa yang dibutuhkan oleh anggota. Keterlibatan perempuan pada kegiatan-kegiatan yang diadakan oleh Program P3EL, diharapkan mampu memecahkan masalah yang mereka hadapi sesuai dengan potensinya.

Program-program dalam P3EL yang disusun (disiapkan) harus memenuhi kebutuhan anggota. Menurut Zamhariri (2008), dalam melakukan analisis kebutuhan harus benar-benar dapat memenuhi kebutuhan (needs analysis), dan bukan sekedar membuat daftar keinginan (list of wants) yang bersifat sesaat. Analisis kebutuhan harus dilakukan secara cermat agar dapat menggali kebutuhan-kebutuhan yang sesungguhnya dibutuhkan oleh anggota P3EL, bukan merupakan keinginan beberapa orang saja, apakah ketua kelompok yang mempunyai kewenangan menentukan keputusan.

\section{Faktor-faktor partisipasi Perempuan dalam Pengentasan Kemiskinan}

Berdasarkan hasil penelitian diperoleh gambaran tentang faktor-faktor yang mendorong partisipasi perempuan terhadap upaya pengentasan kemiskinan berbasis pemberdayaan melalui Program P3EL, sebagai berikut :

1. Motif egoisme

Motif ini memiliki tujuan utama untuk meningkatkan kesejahteraan diri sendiri (Batson, dkk.,2002). Partisipasi perempuan (anggota Program P3EL) pada Program P3EL dilandasi oleh adanya kebutuhan untuk meningkatkan pendapatan ekonomi keluarganya. Perempuan yang tergabung dalam Program P3EL memperoleh pinjaman modal untuk mengembangkan kegiatan usaha, sehingga bisa membantu menopang kebutuhan hidup keluarganya. Melalui pinjaman modal tersebut, perempuan bisa memulai atau melanjutkan kegiatan usaha. Penambahan pendapatan ekonomi bisa menghindarkan ibu-ibu dari para rentenir yang masih banyak beroperasi di desa-desa dengan bunga tinggi dan pembayarannya yang dikejar-kejar.

Partisipasi perempuan sebagai anggota Program P3EL pada kegiatan pelatihan yang diselenggarakan oleh pelaksana program didasari oleh adanya kebutuhan untuk meningkatkan ketrampilan anggota dalam mengelola kegiatan usaha ekonomi produktif, mereka ingin memperoleh tambahan wawasan atau pengetahuan dalam bidang ketrampilan, seperti menjahit, menyulam, membuat kue, membuat bandeng duri lunak, dan sebagainya.

Motif yang mendasari partisipasi perempuan sebagai anggota dalam kegiatan-kegiatan Program P3EL cenderung pada motif egoisme, merupakan motif yang berkaitan dengan mementingkan kesejahteraan diri, yaitu untuk menambah pengalaman tentang kegiatan produksi. Motif egoisme inilah yang pada akhirnya 
mengakibatkan soliditas kelompok P3EL kurang kuat karena masingmasing anggota disibukkan dengan pengembangan usahanya sendirisendiri. Berkaitan dengan hal ini, diperlukan upaya untuk penguatan kelompok sehingga akhirnya menumbuhkan kebersamaan dan rasa memiliki kelompok untuk bersamasama mengatasi persoalan kemiskinan, selanjutnya bisa menumbuhkan motif collectivism yang tinggi yaitu bertujuan untuk meningkatkan kesejahteraan kelompok. Selain itu, semua anggota perlu diberikan kesempatan atau didorong untuk berpartisipasi pada seluruh kegiatan-kegiatan Program P3EL.

\section{Motif collectivisme}

Selain motif egoisme, partisipasi perempuan yang menjadi anggota Program P3EL juga dilandasi oleh motif collectivisme yang bertujuan untuk meningkatkan kesejahteraan kelompok (Batson, dkk., 2002). Program P3EL sebagai program pemberdayaan perempuan untuk mengentaskan kemiskinan memang menerapkan pendekatan kelompok, sehingga partisipasi anggota didorong oleh keinginan untuk membentuk jaringan kerja dan memperoleh dukungan sosial dari anggota lain dalam kelompok sebagai upaya untuk mengatasi persoalan kemiskinan. Melalui kelompok, anggota bisa berbagi pengalaman dalam kegiatan produksi, karena jika dilakukan secara sendirisendiri, anggota merasa sulit untuk dapat memecahkan masalah-masalah yang dihadapinya. Selain itu, lingkup bantuan menjadi terlalu luas jika penanganannya dilakukan secara individu.

Pembentukan kelompok sebagai sasaran Program P3EL juga mendorong tumbuhnya self-efficacy pada anggota. Melalui dukungan antar anggota dalam kelompok membuat anggota lebih yakin dengan kemampuannya sendiri. Self efficacy menjadi lemah ketika tidak ada atau kurang dukungan dari lingkungan sosial seperti kelompok (social persuassion). Bentuk persuasi sosial bisa bersifat verbal dan non verbal yaitu berupa pujian, dorongan dan sejenisnya.

\section{KESIMPULAN}

Kesimpulan yang diperoleh dari penelitian ini sebagai berikut :

1. Bentuk partisipasi perempuan (anggota Program P3EL) terhadap upaya pengentasan kemiskinan berbasis pemberdayaan pada Program P3EL di Kabupaten Sidoarjo, bisa diklasifikasikan sebagai berikut :

a. Partisipasi dalam bentuk tenaga (physical participation), yaitu partisipasi berupa tenaga dengan melibatkan diri dalam suatu aktifitas dengan maksud tertentu. Perempuan yang menjadi anggota Program P3EL berpartisipasi dalam kegiatan pelatihan peningkatan ketrampilan, yang diselenggarakan oleh pihak BPMPKB sebagai pelaksana Program P3EL di Sidoarjo. Meskipun, kegiatan pelatihan tersebut tidak bisa diikuti oleh semua anggota Program P3EL, dan terkadang kurang sesuai dengan kebutuhan anggota.

b. Partisipasi yang berupa kerjasama atau networking antar anggota kelompok. Perempuan yang tergabung dalam Program P3EL berpartisipasi dengan membentuk jaringan kerjasama antar anggota dalam kelompoknya untuk memperoleh dukungan sosial dari anggota lain sebagai upaya untuk mengatasi persoalan kemiskinan.

c. Partisipasi berupa sumbangan pemikiran (psychological participation). Wujud partisipasinya yaitu keikutsertaan secara aktif dengan mengerahkan pikiran dalam suatu rangkaian kegiatan untuk 
mencapai tujuan tertentu. Anggota Program P3EL yang terdiri dari perempuan ini memberikan sumbangan pemikiran berupa usulan-usulan tentang kegiatan pelatihan yang memang dibutuhkan bagi anggota.

2. Faktor-faktor yang mendorong partisipasi perempuan terhadap upaya pengentasan kemiskinan berbasis pemberdayaan pada Program P3EL di Kabupaten Sidoarjo, sebagai berikut:

a. Motif egoisme, memiliki tujuan utama untuk meningkatkan kesejahteraan diri sendiri. Partisipasi perempuan (anggota Program P3EL) dilandasi oleh adanya kebutuhan untuk meningkatkan pendapatan

\section{DAFTAR PUSTAKA}

Amandasani, Dwi. 2011. Partisipasi Masyarakat Dalam Penerapan Rehabilitasi Mental Bagi Penderita Psikosis di Griya Cinta Kasih Jombang. Tesis tidak diterbitkan.

Arbiyah, N. dan Imelda, F.N., dan Oriza, I.D. 2008. Hubungan Bersyukur Dan Subjective Well-Being Pada Penduduk Miskin. JPS Vol. 14 No.01.

Arnstein, S,R. 1969. A Ladder of Citizen Participation. Journal of the American Planning Association, 35(4), 216-224.

Bainar dan Halik, A. 1999. Jagat Wanita: Dalam Pandangan Para Tokoh Dunia. Jakarta : PT. PusakaCidesindo.

Batson, C.D.,Ahmad, N., dan Tsang, J. 2002. Four Motives for Community Involvement. Journal of Social Issues, 58 (3):429-445. ekonomi keluarganya. Perempuan yang tergabung dalam Program P3EL memperoleh pinjaman modal untuk mengembangkan kegiatan usaha, sehingga bisa membantu menopang kebutuhan hidup keluarganya.

b. Motif collectivism, bertujuan untuk meningkatkan kesejahteraan kelompok. Partisipasi perempuan yang menjadi anggota Program P3EL juga didorong oleh keinginan untuk membentuk jaringan kerja dan memperoleh dukungan sosial dari anggota lain dalam kelompok sebagai upaya untuk mengatasi persoalan kemiskinan dalam kelompoknya.
BPMPKB. 2012. Pedoman Umum Pengelolaan Dana Bergulir Kelompok Pemberdayaan Perempuan Pengembang Ekonomi Lokal (P3EL) Kabupaten Sidoarjo.

Brodjonegoro, S. 2007. Pencapaian MDGs dan Prioritas Pembangunan Ekonomi Indonesia. Depok : Lokakarya Dewan Guru Besar Universitas Indonesia.

Campbell, C. dan Gillies, P. 2001. Conceptualizing 'social capital' for health promotion in small local communities : a micro-qualitative study. Journal of community and applied social psychology 11:329346.

Diener, E., dan Seligman, M.E.P. 2004. Beyond money: Toward an economy of well-being. Psychological Science in the Public Interest, 5, 1-31.

$$
\begin{aligned}
& \text { Dufy, K.G dan Wong, F.Y. } \\
& \text { 2003.Community } \\
& \text { Boston:Allyn \& Bacon. }
\end{aligned}
$$


Gaventa, J. Dan Valderama. 2001. Partisipasi, Kemasyarakatan, dan pemerintah Daerah, dalam pengantar buku, Mewujudkan Partisipasi; Teknik, Partisipasi MasyarakatUntuk Abad 21, The British Council \& New Economics Fondation.

Holil, Soelaiman. 1980. Partisipasi Sosial Dalam Usaha Kesejahteraan Sosial. Bandung:ITB.

Isbandi, Rukminto. 2007. Perencanaan Partisipatoris Berbasis Aset Komunitas : dari Pemikiran Menuju Penerapan. Depok : FISIP UI Press.

Kumurur, V.A. 2009. Pembangunan Dan Kemiskinan Perempuan Di Kota. Jurnal Ekoton Vol. 9 No. 1.

Markum, E. 2009. Pengentasan Kemiskinan Dan Pendekatan Psikologi Sosial. Jurnal Psikobuana Vol.1 No.1, 1-12.

Maskun, S. 1997. Pembangunan Masyarakat Desa, Asas, Kebijaksanaan, dan Manajemen. Yogyakarta : Media Widya Mandala.

Masruroh, H. 2005. Pola pendidikan anak dari keluarga miskin. Semarang:Universitas Negeri Semarang, Fakultas Ilmu Pendidikan.

Moleong, L.J. 2009. Metodologi Penelitian Kualitatif. Bandung : Remaja Rosdakarya.

Mulia, N., dan Schmidt, L., dan Bond, J., dan Jacobs, L., dan Korcha, R. 2008. Stress, social support and problem drinking among women in poverty. Journal ompilation Society for the study of addiction Vol. 103.
Nelson, G dan Prilleltensky, I. 2005. Community Psychology In Pursuit of Liberation and Well Being. New York:Palgrave Macmillan.

Orford, J. 2008. Community Psychology, Challenges, Controversies and Emerging Consensus, School of Psychology. The University of Birmingham, UK : John Wiley and Sons, Ltd.

Poerwandari, E.K. 2005. Pendekatan Kualitatif dalam Penelitian Psikologi. Jakarta : Universitas Indonesia.

Pranaka dan Moeljarjo. 2001. Membangun SDM dan Kapabilitas Teknologi Umat (Solusi Untuk Bangkit Dari Krisis dan Memasuki Dinamika Milenium Ketiga). Jakarta : ISTECS.

Prijono, O. dan Pranaka. 1996. Pemberdayaan : Konsep, Kebijakan, dan Implementasi. Jakarta:CSIS.

Ridaningrum, T. 2008. Efektivitas Program P3EL di Kelurahan Medokan Wetan Kota Surabaya. Skripsi. FISIP UNAIR.

Rudkin, J.K. 2003. Community Psychology (Guiding Principles And Orienting Coccepts). USA : Prentice Hall.

Smith, A. 2008. Applying the Lessons Learnt : Community Involvement in Regeneration. Journal of Public Policy and Administration, 23:145152.

Sukesi, K., dkk. 2002. Jaminan Sosial Tenaga Kerja Perempuan Sektor Informal. Pusat Penelitian Peran Wanita Lembaga Penelitian Universitas Brawijaya Malang.

Wibowo, Istiqomah, dkk. 2011. Psikologi

Komunitas. Jakarta : LPSP3 UI. 